\title{
Meconium Induces Expression of Inducible NO Synthase and Activation of NF- $\kappa$ B in Rat Alveolar Macrophages
}

\author{
YING-HUA LI, ZHONG-QUN YAN, ANNELIE BRAUNER, AND KJELL TULLUS \\ Neonatal Unit [Y.-H.L.] and Pediatric Nephrology [K.T.], Astrid Lindgren Children's Hospital, \\ Karolinska Institute, Stockholm, Sweden; and Center for Molecular Medicine [Z.-Q.Y.] and Department of \\ Clinical Microbiology [Y.-H.L., A.B.], Karolinska Hospital, Stockholm, Sweden
}

\begin{abstract}
Meconium aspiration causes intensive inflammatory reactions in the lungs, and may lead to neonatal respiratory disorder. Infiltrated inflammatory cells, particularly macrophages, play an important role in such an inflammation. A rat alveolar macrophage cell line (ATCC8383) was exposed to meconium alone or in combination with dexamethasone, budesonide, or interferon- $\gamma$. Nitric oxide (NO) accumulation in the supernatant of the cell culture was detected by Griess reaction, and mRNA of inducible NO synthase (iNOS) expression was detected by reverse transcriptase-PCR. Nuclear factor-kappa B was analyzed by electrophoretic mobility shift assay, and iNOS location and nuclear factor-kappa B transactivation were determined by immunostaining. Our results showed that meconium was capable of inducing production of $\mathrm{NO}$ and expression of iNOS in alveolar macrophages in a dose- $(1-25 \mathrm{mg} / \mathrm{mL}, p<0.05)$ and time$(4-48 \mathrm{~h}, p<0.05)$ dependent manner. This capability of meconium could be further enhanced in the presence of interferon- $\gamma$ $(100 \mathrm{IU} / \mathrm{mL}, p<0.05)$. Budesonide $\left(10^{-4}-10^{-10} \mathrm{M}\right)$ or dexamethasone $\left(10^{-4}-10^{-6} \mathrm{M}\right)$ effectively inhibited the meconiuminduced NO production $(p<0.05)$. Using the protein synthesis inhibitor cycloheximide, we demonstrated that meconium directly induced iNOS in macrophages. Furthermore, meconium
\end{abstract}

\section{ABSTRACT}

also triggered nuclear factor-kappa B activation, a mechanism possibly responsible for the iNOS expression. Our findings suggest that meconium is a potent inflammatory stimulus, resulting in iNOS expression, leading to overproduction of NO from the macrophages, which may be of pathogenic importance in meconium aspiration syndrome. In vitro steroids down-regulated the iNOS expression, thus suggesting a potential to down-regulate NO-mediated inflammation in neonates with meconium aspiration syndrome. (Pediatr Res 49: 820-825, 2001)

LPS, lipopolysaccharide

Abbreviations:

RT-PCR, reverse transcriptase-PCR

NO, nitric oxide

iNOS, inducible nitric oxide synthase

IFN- $\boldsymbol{\gamma}$, interferon- $\gamma$

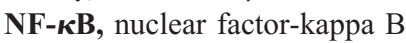

CHX, cycloheximide

EMSA, electrophoretic mobility shift assay

MAS, meconium aspiration syndrome

$\mathrm{NO}_{2}{ }^{-}$, nitrite

G3PDH, glyceraldehyde-3-phosphate dehydrogenase
Meconium-stained amniotic fluid is frequently encountered during both term and postterm deliveries, and $1-3 \%$ of affected infants consequently develop MAS. This disorder is characterized by respiratory distress complicated with persistent pulmonary hypertension caused by airway obstruction and pneumonitis. MAS is a major cause of neonatal morbidity and mortality (1).

Received July 4, 2000; accepted November 7, 2000.

Correspondence and reprint requests: Kjell Tullus, Astrid Lindgren Children's Hospital, Karolinska Institutet, SE-171 76 Stockholm, Sweden; e-mail: Kjell.Tullus@ks.se

Supported by Stiftelsen Frimurare Barnhuset, the Founds of Karolinska Institute, Magn. Bergvalls foundation, Stiftelsen Sven Jerrings Fond, Sällskapet Barnavård Foundation, the Swedish Medical Research Council (project 6816), the Swedish Heart-Lung Foundation (199941318), and Tore Nilsson Foundation.

Part of this study has been presented at the 4th International Congress on Pediatric Pulmonology in Nice, France, 2000, and the first author received the Lung and Childhood Young Investigator Award.
NO is an important molecule active in a number of biologic reactions $(2,3)$, especially with implications in inflammation (4). It is generated from L-arginine by three different NO synthases; of these, two are constitutive isoforms. The third is an inducible and $\mathrm{Ca}^{2+}$-independent $\mathrm{NO}$ synthase (iNOS), normally produced only after transcriptional activation of its gene $(5,6)$. High levels of NO produced by iNOS can mediate lung injury (7). Laboratory studies have suggested that NO can potentiate the lung injury by promoting oxidative or nitrosative stress (8), inactivating surfactant, and stimulating inflammation (9).

The expression of iNOS is mediated by differential signaling transduction pathways. Among them, the NF- $\kappa \mathrm{B}$ signaling pathway has been suggested as the determinant mechanism, for example, for cytokine production, regulation of adhesion mol- 
ecules, and acute-phase protein synthesis (10). NF- $\kappa \mathrm{B}$ may be induced by many endogenous and exogenous stimuli.

The purpose of this study was to investigate whether meconium could stimulate macrophages to produce $\mathrm{NO}$, express iNOS, and activate NF- $\kappa \mathrm{B}$ in vitro and further to evaluate the effect of dexamethasone and budesonide on NO production.

\section{METHODS}

Cell culture. A rat alveolar macrophage cell line (ATCC8383, Rockville, MD, U.S.A.) was maintained in Ham's F-12 medium (GibcoBRL, Gaithersburg, MD, U.S.A.) supplemented with $15 \%$ heat-inactivated fetal bovine serum Myclone (GibcoBRL).

Preparation of meconium. Meconium was collected from the first stools of three healthy newborn infants. It was pooled, resuspended in sterile PBS, filtered, and subsequently irradiated. No bacterial growth was found from meconium. Endotoxin levels in the meconium were $<10 \mathrm{pg} / \mathrm{mL}$ as assessed by the Limulus amebocyte lysate endochrome test (Charles River Endosafe, Charleston, SC, U.S.A.). The sterile pooled suspension was then stored at $-20^{\circ} \mathrm{C}$ for later use.

Antigen stimulation and effect of steroids on NO production. The rat alveolar macrophages were distributed into 24microwell plates at a concentration of $1 \times 10^{6}$ cells $/ \mathrm{mL}$ in serum- and phenol red-free medium. They were stimulated with either $1-25 \mathrm{mg} / \mathrm{mL}$ meconium, or $100 \mathrm{ng} / \mathrm{mL}$ LPS (O55:B5, Sigma Chemical Co., St. Louis, MO, U.S.A.) alone or in combination with $100 \mathrm{IU} / \mathrm{mL}$ IFN- $\gamma$ (Genzyme, Cambridge, MA, U.S.A.) for $24 \mathrm{~h}$ at $37^{\circ} \mathrm{C}$, in $5 \% \mathrm{CO}_{2}$. Meconium $(5 \mathrm{mg} / \mathrm{mL})$ was also incubated with the macrophages for different periods $(4-48 \mathrm{~h})$. For the effect of steroids on NO production, the rat alveolar macrophages were incubated with $5 \mathrm{mg} / \mathrm{mL}$ of meconium in combination with dexamethasone $\left(10^{-4}-10^{-10} \mathrm{M}\right)$ or budesonide $\left(10^{-4}-10^{-10} \mathrm{M}\right)$. To investigate whether meconium has a direct effect on NO production, the macrophages were incubated with $5 \mathrm{mg} / \mathrm{mL}$ of meconium in combination with the protein synthetase inhibitor CHX (1 $\mu \mathrm{g} / \mathrm{mL}$, Sigma Chemical Co.) for $24 \mathrm{~h}$. Supernatants were collected after stimulation and stored at $-70^{\circ} \mathrm{C}$ for analysis.

$\mathrm{NO}_{2}^{-}$assay. The accumulation of $\mathrm{NO}_{2}^{-}$, a stable end product of NO formation, in conditioned media was measured as an indicator of NO production. One hundred microliters of cell-free conditioned medium was incubated for $10 \mathrm{~min}$ with $100 \mu \mathrm{L}$ of Griess reagent at room temperature, and the absorbance at a wavelength of $540 \mathrm{~nm}$ was automatically measured in a microplate reader. $\mathrm{NO}_{2}{ }^{-}$in the samples was calculated using a standard curve of sodium nitrite.

$\boldsymbol{R T}$-PCR. Total RNA was extracted from cells with RNAzolB (Biotecx Laboratories; Houston, TX, U.S.A.) according to the manufacturer's instructions. First-strand cDNA synthesis of total RNA was performed using SuperScript RNase $\mathrm{H}^{-}$ Reverse Transcriptase (GibcoBRL) and random hexamer primers [pd(N) ${ }_{6}$; Amersham Pharmacia Biotech, Uppsala, Sweden]. Specific oligonucleotide primers were synthesized for rat iNOS (Clontech, Palo Alto, CA, U.S.A.). The sequences of the 3'and 5'-primers used are 5'-CCCTTCCGAAGTTTCTGGCAGCAG-3' and 5'-GGGCTCCTCCAAGGTGTTGCCC-3' (11).
The rat G3PDH primer (Innovagen, Lund, Sweden) sequences are 5'-CTCAAGATTGTCAGCAATGC-3' and 5'-CAGGATGCCCTTTAGTGGGC-3' (12). The PCR using Taq polymerase (final concentration, $0.025 \mathrm{U} / \mu \mathrm{L}$; GibcoBRL) was performed in a final volume of $25 \mu \mathrm{L}$ containing $2 \mu \mathrm{L}$ of cDNA for iNOS and G3PDH in a DNA Thermocycler 480 (Perkin Elmer, Norwalk, CT, U.S.A.) for 33 cycles for rat iNOS under the following conditions: $1 \mathrm{~min}$ denaturation at $94^{\circ} \mathrm{C}, 1 \mathrm{~min}$ annealing at $60^{\circ} \mathrm{C}$, and 2 min extension at $72^{\circ} \mathrm{C}$. PCR was conducted for rat $\mathrm{G} 3 \mathrm{PDH}$ with $1 \mathrm{~min}$ at $94^{\circ} \mathrm{C}, 1 \mathrm{~min}$ at $60^{\circ} \mathrm{C}$, and $1 \mathrm{~min}$ at $72^{\circ} \mathrm{C}$. The PCR products were separated on a $1.5 \%$ agarose gel (GibcoBRL). The ethidium bromide-stained gel was photographed under UV light with the DC120 Digital Zoom Camera (Eastman Kodak, Rochester, NY, U.S.A.).

EMSA. Cells grown in serum-free medium were stimulated with meconium for 15, 30, and $60 \mathrm{~min}$. Nuclear extracts were prepared as described (13), and nuclear protein concentrations were determined using the bicinchoninic acid kit (Pierce, Rockford, IL, U.S.A.). The nuclear extract (3 $\mu$ g of protein) was preincubated for $10 \mathrm{~min}$ in the reaction buffer $[10 \mathrm{mM}$ HEPES, pH 7.9, 10\% glycerol, $60 \mathrm{mM} \mathrm{KCl,} 5 \mathrm{mM} \mathrm{MgCl}_{2}, 0.5$ mM EDTA, 1 mM DTT, $1 \mathrm{mM}$ phenylmethylsulfonyl fluoride, and $2 \mu \mathrm{g}$ poly (dI-dC)], followed by incubation for $30 \mathrm{~min}$ at room temperature with $50,000 \mathrm{cpm}$ of ${ }^{32} \mathrm{P}$-labeled NF- $\kappa \mathrm{B}$ probe (double-stranded oligonucleotides containing an NF- $\kappa \mathrm{B}$ consensus binding site: 5'-AGTTGAGGGGACTTTCCCAGGC-3', Promega, Madison, WI, U.S.A.). After $30 \mathrm{~min}$ at room temperature, samples were separated on a $4 \%$ native polyacrylamide gel in low ionic strength buffer $(22.3 \mathrm{mM}$ Tris-borate, 0.5 mM EDTA, pH 8). Dried gels were autoradiographed with intensive screens at $-80^{\circ} \mathrm{C}$. In some cases, the incubation of nuclear extracts with ${ }^{32} \mathrm{P}$-labeled NF- $\kappa \mathrm{B}$ probe was performed in the presence of excess unlabeled NF- $\kappa \mathrm{B}$ probe or the irrelevant oligonucleotide, AP-1 (Promega).

Transactivation of $N F-\kappa B$ and immunolocalization of iNOS. Cells (3000/well) were plated on glass coverslips and incubated with meconium, $5 \mathrm{mg} / \mathrm{mL}, 30 \mathrm{~min}$ for NF- $\kappa \mathrm{B}$ and $24 \mathrm{~h}$ for iNOS. After treatment, the cells were fixed with cold methanol and acetone. Intracellular p65 and iNOS were visualized by indirect immunofluorescence using polyclonal rabbit anti-p65 antibodies (Santa Cruz Biotechnology, Santa Cruz, CA, U.S.A.) and polyclonal rabbit anti-macrophage iNOS antibodies (Affinity BioReagents, Golden, CO, U.S.A.), followed by FITC-labeled goat anti-rabbit IgG (Dako, Copenhagen, Denmark).

Data analysis. Data from pooled experiments were reported as the mean $\pm \mathrm{SEM} \mathrm{NO}{ }_{2}{ }^{-}$concentrations (micromolar). Data were analyzed by Student's $t$ test or one-way ANOVA. A $p<$ 0.05 was considered to be significant.

\section{RESULTS}

NO production and iNOS expression. Meconium stimulated the production of $\mathrm{NO}$ from the alveolar macrophages in a dose- and time-dependent manner (Fig. 1). All tested concentrations $>1 \mathrm{mg} / \mathrm{mL}$ meconium stimulated the production of NO compared with the control samples $(p<0.05)$ at $24 \mathrm{~h}$. Five milligrams per milliliter meconium itself contains $5.06 \pm 0.79$ 
$\mu \mathrm{M} \mathrm{NO}_{2}{ }^{-}$. The NO production was already stimulated after $4 \mathrm{~h}$ incubation with $5 \mathrm{mg} / \mathrm{mL}$ meconium $(p<0.05)$ and continuously increased during the studied $48 \mathrm{~h}(p<0.05)$. The capability of meconium to stimulate NO production was further enhanced in the presence of IFN- $\gamma(100 \mathrm{IU} / \mathrm{mL}, p<0.05$; Fig. 1A).

Because iNOS is regulated mainly at the transcriptional level, iNOS transcripts were examined by RT-PCR. Meconium stimulated macrophages to express higher levels of iNOS mRNA compared with untreated macrophages (Fig. 2). The iNOS protein was also shown in the meconium-stimulated cells with immunostaining techniques (Fig. $3 A$ ).

To detect whether meconium has a direct effect on iNOS expression, we used the protein synthetase inhibitor $\mathrm{CHX}$ to block the de novo synthesis of, for example, cytokines. As shown in Figure 2, the induction of macrophage iNOS expression by meconium was not dependent on cytokine production.

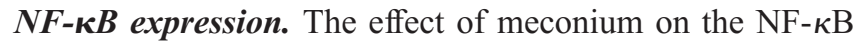
signal transduction pathway in the alveolar macrophages was determined by EMSA. No clear effect was seen after a 15-min treatment with meconium. After 30 and 60 min, the NF- $\kappa \mathrm{B}$ binding complexes observed were substantially enhanced in the nuclear extracts of the macrophages (Fig. 4). The specific-
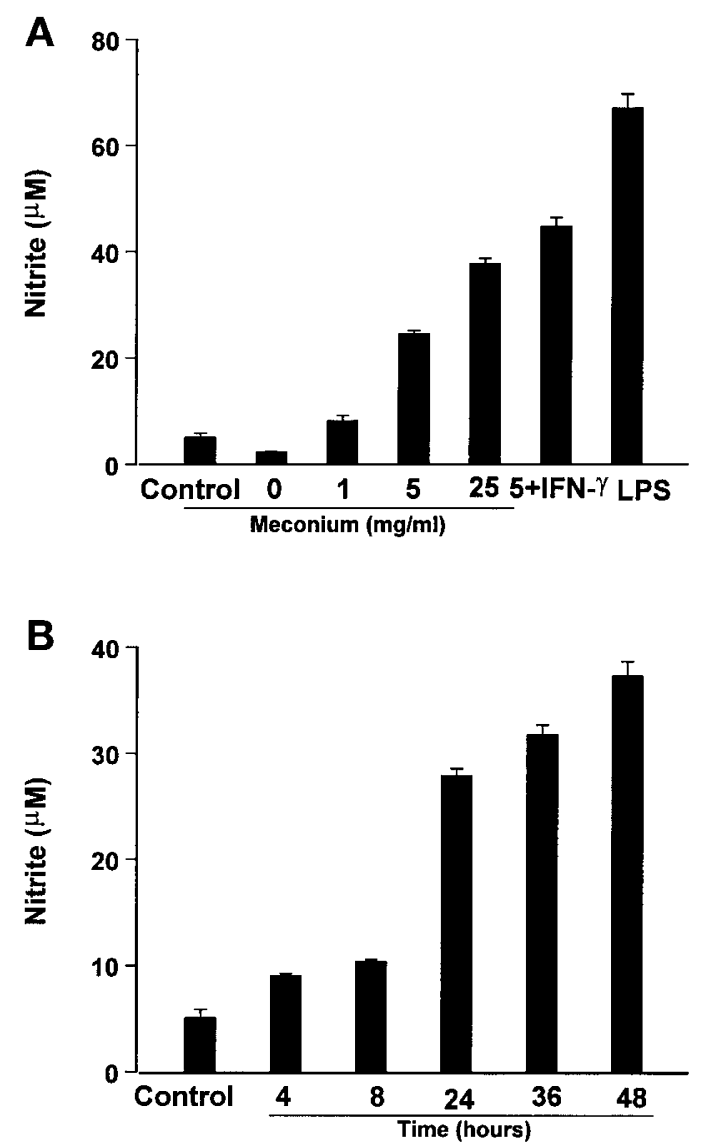

Figure 1. $A$, NO production after $24 \mathrm{~h}$ stimulation in the rat alveolar macrophage cell line with LPS (100 ng/mL), meconium (1-25 mg/mL), and meconium $(5 \mathrm{mg} / \mathrm{mL})$ in combination with IFN- $\gamma(100 \mathrm{IU} / \mathrm{mL})$. Control denotes the concentration of $\mathrm{NO}_{2}{ }^{-}$in $5 \mathrm{mg} / \mathrm{mL}$ meconium. $\mathrm{NO}$ activity was assessed by determining $\mathrm{NO}_{2}{ }^{-}$concentration in conditioned medium. $B$, NO production after stimulation with $5 \mathrm{mg} / \mathrm{mL}$ meconium at different times. NO production increases with time.

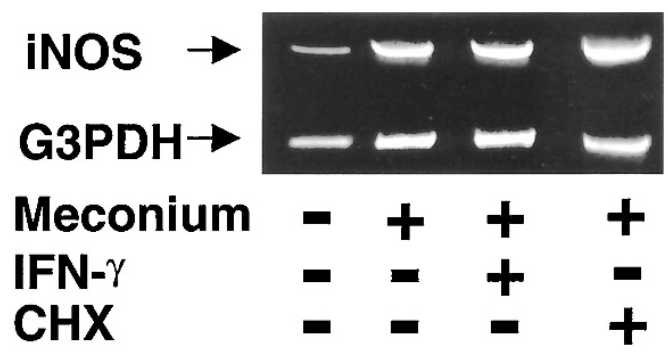

Figure 2. Expression of iNOS in the macrophages studied with RT-PCR after stimulation with $5 \mathrm{mg} / \mathrm{mL}$ meconium alone or together with IFN- $\gamma(100$ $\mathrm{IU} / \mathrm{mL})$ or $\mathrm{CHX}(1 \mu \mathrm{g} / \mathrm{mL})$.

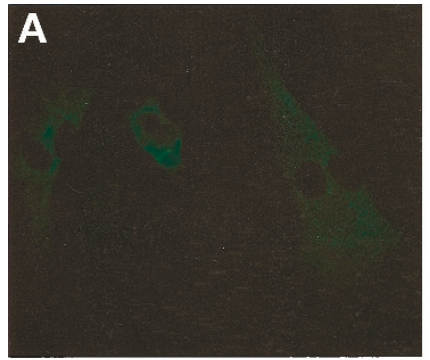

Unstimulated

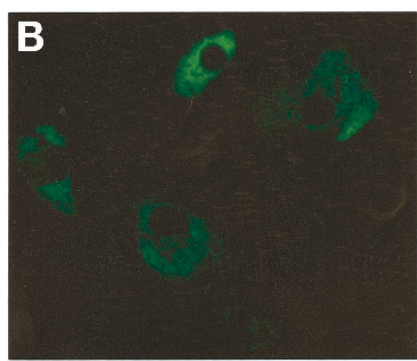

Unstimulated

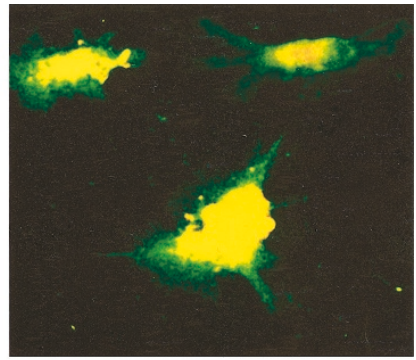

Meconium

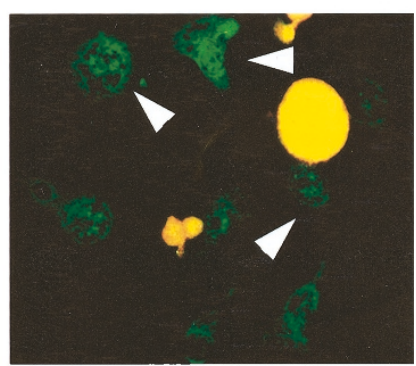

Meconium
Figure 3. $A$, immunostaining of the rat alveolar macrophages for iNOS after stimulation with $5 \mathrm{mg} / \mathrm{mL}$ meconium compared with unstimulated cells. Original magnification $\times 500$. $B$, immunostaining for $\mathrm{NF}-\kappa \mathrm{B}$ expression after 30 -min incubation with $5 \mathrm{mg} / \mathrm{mL}$ meconium compared with unstimulated cells. The intracellular location of p65 was detected by indirect immunofluorescence with an anti-p65 antibody. Arrowheads indicate the transactivated $\mathrm{NF}-\kappa \mathrm{B}$. Original magnification $\times 500$.

ity of the NF- $\kappa \mathrm{B}-\mathrm{DNA}$ complex was ascertained by competition study. As shown in Figure 4, the indicated NF- $\kappa$ B-DNA complexes were removed by excessive cold NF- $\kappa$ B probe but were not affected by excessive AP-1 probe. The activated expression of NF- $\kappa \mathrm{B}$ was also determined by immunostaining in terms of the translocation of $\mathrm{p} 65$ in cells treated by meconium for $30 \mathrm{~min}$ and in untreated cells. In the untreated macrophages, p65 was sequestered in the cytoplasm; whereas in the cells treated with meconium $(5 \mathrm{mg} / \mathrm{mL})$, translocation of p65 into the nuclei of the macrophages was seen (Fig. $3 B$ ).

Down-regulation of NO production by steroids. Budesonide $\left(10^{-4}-10^{-10} \mathrm{M}\right)$ and dexamethasone $\left(10^{-4}-10^{-6} \mathrm{M}\right)$ significantly inhibited NO production stimulated by meconium $\left(p<0.05\right.$; Fig. 5). Budesonide $\left(\geq 10^{-6} \mathrm{M}\right)$ was more potent than dexamethasone at the same concentration $(p<0.05)$. 


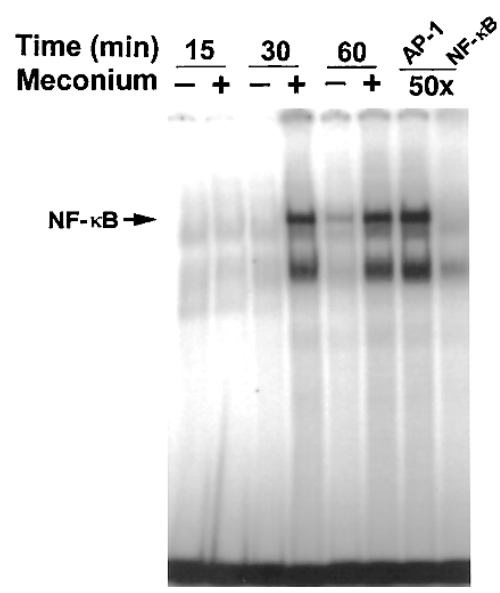

Figure 4. NF- $\kappa \mathrm{B}$ binding complexes studied by EMSA. After treatment with meconium for 30 and $60 \mathrm{~min}, \mathrm{NF}-\kappa \mathrm{B}$ binding complexes were substantially enhanced. No alteration was observed after $15 \mathrm{~min}$. The indicated NF- $\kappa \mathrm{B}-$ DNA complexes were removed by $50 \times$ excessive cold NF- $\kappa$ B probe but not by excessive AP-1 probe.

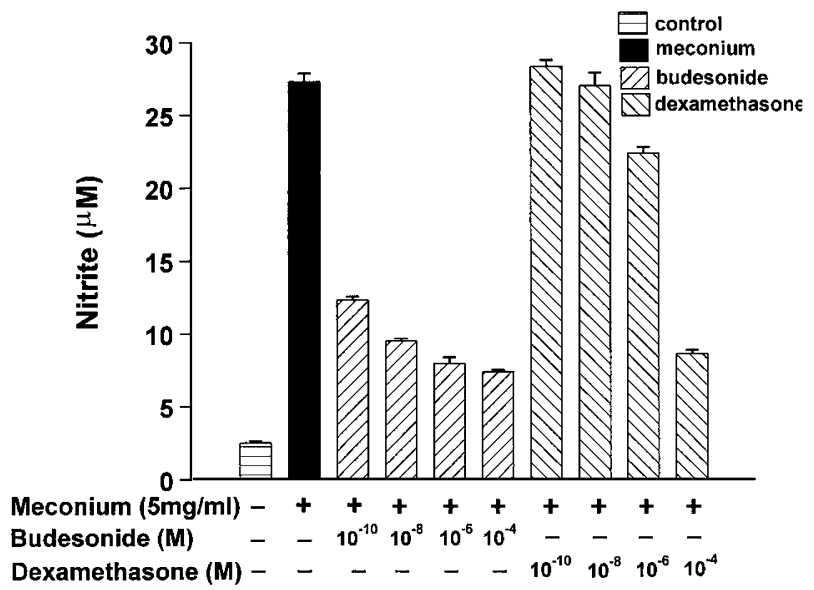

Figure 5. Down-regulation of $5 \mathrm{mg} / \mathrm{mL}$ meconium-stimulated NO production in the rat alveolar macrophage cell line by different doses of budesonide and dexamethasone.

\section{DISCUSSION}

We have, for the first time, shown that meconium could induce iNOS gene expression and lead to high output of NO from alveolar macrophages in a dose-dependent way. CHX did not affect the iNOS mRNA expression, indicating that meconium had a direct effect, not via cytokine production, on the NO production. Both budesonide and dexamethasone downregulated the meconium-stimulated NO production. Likewise, $\mathrm{NF}-\kappa \mathrm{B}$ was also activated by meconium.

The mechanisms for the development of MAS are not completely understood. After meconium aspiration, an intense inflammatory response occurs, with polymorphonuclear lymphocytes found diffusely through the lungs. This inflammatory reaction, supposedly initiated by meconiuminduced activation of pulmonary macrophages (14), is associated with increased pulmonary vascular permeability, leading to proteinaceous exudation into the alveolar spaces, and thereby inactivation of pulmonary surfactant and decreased lung compliance. In vitro studies have indicated that the neutrophils and plasma proteins accumulating in the alveoli as a result of the inflammatory response are potential inhibitors of surfactant (15), which may also explain why meconium can inactivate surfactant (16). It has previously been shown that meconium could stimulate IL-8 expression (17) and inhibit neutrophil oxidative burst and phagocytosis (18), and high levels of IL-6 in meconium-stained amniotic fluid have been detected (19). Meconium aspiration may also cause apoptosis in epithelial cells (20). All these inflammatory reactions, together with our present findings, may be part of the pathologic basis of MAS and lead to not only structural changes in the neonate, such as complete obstruction of the upper airways, atelectasis, pulmonary interstitial emphysema, or chemical pneumonitis, but also several physiologic changes, such as hypoxemia, hypercapnia, acidosis $(21,22)$, persistent pulmonary hypertension, and even death (23-25). There exist several mechanisms through which relatively high levels of NO produced by iNOS can mediate lung injury (7). Reaction of NO with superoxide anions produces peroxynitrite, which is a highly oxidative species that is capable of nitrating tyrosine residues of numerous proteins, leading to the formation of nitrotyrosine. High levels of nitrotyrosine formation have been shown to be involved in acute lung injury in humans and LPS-injected animals.

Clinical studies have suggested that NO is an important inflammatory mediator in critically ill patients (26-28), especially in neonatal fulminant early onset pneumonia (29). Likewise, monocytes and tissue macrophages isolated from patiens with rheumatoid arthritis, tuberculosis, and malaria display higher levels of iNOS and generate increased levels of NO in vitro (30). It is known that there are species differences of $\mathrm{NO}$ production. Weinberg (30) has reviewed the reports from 1989 to 1998 regarding NO production and iNOS expression in human mononuclear phagocytes in which there were some difficulties in detecting NO production, partly depending on the method used. Rodent mononuclear phagocytes have been used for many in vitro studies $(31,32)$, mainly because they are more sensitive.

NO has now acquired considerable notoriety as a representative of a new class of messenger molecules that are responsible for various functions in many different tissues. Although the physiologic production of NO plays a key role in the host-defense response against various intracellular pathogens, its overproduction may be responsible in part for the pathophysiology of infection (33). NO is produced by cells responsible for a number of different functions in the vascular endothelium (34), cells of the immune system (35), smooth muscle (36), and cardiac muscle (37). High-output NO may cause increased permeability of vascular endothelial cells, inhibit leukocyte adhesion, degrade carbohydrates, inhibit lipid peroxidation, and cleave DNA via nitrosation, nitration, and oxidation, and thus may lead to the pathophysiologic changes in MAS.

There are reports of clinically beneficial effects of NO inhalation with some limitations and side effects. Nitric oxide therapy seems to reduce the need for extracorporeal membrane oxygenation (38), but has no apparent effect on mortality in 
critically ill infants with hypoxic respiratory failure (39). Treatment with high-frequency oscillatory ventilation plus inhaled NO is often more successful than treatment with highfrequency oscillatory ventilation or inhaled $\mathrm{NO}$ alone in severe persistent pulmonary hypertension of the newborn (40). Early continuous NO inhalation controls the rise in pulmonary artery pressure and improves the efficiency of arterial oxygenation, and further prevents the increase in epithelial apoptosis, but does not protect against early inflammatory damage caused by meconium aspiration (41). In the newborn pig model of MAS, short-term exposure to inhaled NO does not decrease pulmonary artery pressure or improve oxygenation (42). The dual effects of NO, the difference between exogenous and endogenous $\mathrm{NO}$, the functional site of $\mathrm{NO}$, and the local concentration of $\mathrm{NO}$ need to be further investigated.

$\mathrm{NF}-\kappa \mathrm{B}$ is known to be a ubiquitous rapid-response transcription factor expressed in a wide variety of cells and involved in the generation of a number of inflammatory gene products (10). A number of endogenous and exogenous stimuli can induce NF- $\kappa \mathrm{B}$ activation. The NF- $\kappa \mathrm{B}$ site in the iNOS promoter region is essential for LPS- or oxidative stress-induced NO production (5). The role of NF- $\kappa \mathrm{B}$ in iNOS gene expression has been well elucidated. Stimulation of macrophages with LPS or other cytokines leads to activation of NF- $\kappa \mathrm{B}$ and subsequently binding to the $\kappa \mathrm{B}$ response element of the iNOS promoter. It has, however, been unclear whether meconium is able to activate NF- $\kappa \mathrm{B}$. Our data demonstrate that meconium is a potent activator of NF- $\kappa \mathrm{B}$, as evidenced by our finding that meconium could trigger a rapid and intense NF- $\kappa$ B activation in macrophages. This suggests that NF- $\kappa \mathrm{B}$ activation may be a key mechanism responsible for the meconium-induced iNOS expression pathway. In addition, the potential role of NF- $\kappa \mathrm{B}$ in inflammation and immune modulation in MAS is not limited to transcriptional activation of iNOS. In fact, NF- $\kappa$ B has been shown to exert a crucial role in the inducible expression of many inflammatory genes encoding transcriptional factors, adhesion molecules, cytokines, and growth factors (43). Therefore, meconium-induced NF- $\kappa \mathrm{B}$ activation in macrophages may represent a key mechanism responsible for the inflammatory reaction associated with MAS.

Management of MAS patients is with mechanical ventilation and the administration of exogenous surfactant or extracorporeal membrane oxygenation (44). Despite significant advances, MAS still causes important morbidity and mortality. Budesonide (an inhaled steroid) and dexamethasone (a systemic steroid) have been used to inhibit the inflammatory response, and they can down-regulate the proinflammatory cytokine production in vitro $(45,46)$. The present study shows that they also inhibited the meconium-stimulated NO production and suggests that steroids could be used in the treatment of MAS.

In conclusion, our findings show that meconium is a potent inflammatory stimulus, resulting in iNOS expression, leading to overproduction of $\mathrm{NO}$ from the macrophages, which could result in MAS.

Acknowledgments. The authors thank Drs. Baldvin Jonsson and Mirelle Vanpee for collecting meconium.

\section{REFERENCES}

1. Katz VL, Bowes Jr WA 1992 Meconium aspiration syndrome: reflections on a murky subject. Am J Obstet Gynecol 166:171-183

2. Hibbs Jr JB, Taintor RR, Vavrin Z 1987 Macrophage cytotoxicity: role for L-arginine deiminase and imino nitrogen oxidation to nitrite. Science 235:473-476

3. Hibbs Jr JB, Taintor RR, Vavrin Z, Rachlin EM 1988 Nitric oxide: a cytotoxic activated macrophage effector molecule. Biochem Biophys Res Commun 157:87-94

4. Grisham MB, Jourd'Heuil D, Wink DA 1999 Nitric oxide. I. Physiological chemistry of nitric oxide and its metabolites: implications in inflammation. Am J Physiol 276:G315-G321

5. Xie QW, Cho HJ, Calaycay J, Mumford RA, Swiderek KM, Lee TD, Ding A, Troso T, Nathan C 1992 Cloning and characterization of inducible nitric oxide synthase from mouse macrophages. Science 256:225-228

6. Lorsbach RB, Murphy WJ, Lowenstein CJ, Snyder SH, Russell SW 1993 Expression of the nitric oxide synthase gene in mouse macrophages activated for tumor cell killing: molecular basis for the synergy between interferon-gamma and lipopolysaccharide. J Biol Chem 268:1908-1913

7. Kristof AS, Goldberg P, Laubach V, Hussain SN 1998 Role of inducible nitric oxide synthase in endotoxin-induced acute lung injury. Am J Respir Crit Care Med 158:1883-1889

8. Beckman JS, Beckman TW, Chen J, Marshall PA, Freeman BA 1990 Apparent hydroxyl radical production by peroxynitrite: implications for endothelial injury from nitric oxide and superoxide. Proc Natl Acad Sci USA 87:1620-1624

9. Issa A, Lappalainen U, Kleinman M, Bry K, Hallman M 1999 Inhaled nitric oxide decreases hyperoxia-induced surfactant abnormality in preterm rabbits. Pediatr Res 45:247-254

10. Lee JI, Burckart GJ 1998 Nuclear factor kappa B: important transcription factor and therapeutic target. J Clin Pharmacol 38:981-993

11. Sirsjo A, Soderkvist P, Sundqvist T, Carlsson M, Ost M, Gidlof A 1994 Different induction mechanisms of mRNA for inducible nitric oxide synthase in rat smooth muscle cells in culture and in aortic strips. FEBS Lett 338:191-196

12. Williams CM, Coleman JW 1995 Induced expression of mRNA for IL-5, IL-6, TNF-alpha, MIP-2 and IFN-gamma in immunologically activated rat peritoneal mast cells: inhibition by dexamethasone and cyclosporin A. Immunology 86:244-249

13. Yan Z, Sirsjo A, Bochaton-Piallat ML, Gabbiani G, Hansson GK 1999 Augmented expression of inducible NO synthase in vascular smooth muscle cells during aging is associated with enhanced NF-kappaB activation. Arterioscler Thromb Vasc Biol $19: 2854-2862$

14. Kojima T, Hattori K, Fujiwara T, Sasai-Takedatsu M, Kobayashi Y 1994 Meconiuminduced lung injury mediated by activation of alveolar macrophages. Life Sci 54:1559-1562

15. Davey AM, Becker JD, Davis JM 1993 Meconium aspiration syndrome: physiological and inflammatory changes in a newborn piglet model. Pediatr Pulmonol 16:101108

16. Higgins ST, Wu AM, Sen N, Spitzer AR, Chander A 1996 Meconium increases surfactant secretion in isolated rat alveolar type II cells. Pediatr Res 39:443-447

17. de Beaufort AJ, Pelikan DM, Elferink JG, Berger HM 1998 Effect of interleukin 8 in meconium on in-vitro neutrophil chemotaxis. Lancet 352:102-105

18. Clark P, Duff P 1995 Inhibition of neutrophil oxidative burst and phagocytosis by meconium. Am J Obstet Gynecol 173:1301-1305

19. Hsieh TT, Hsieh CC, Hung TH, Chiang CH, Yang FP, Pao CC 1998 Differential expression of interleukin- 1 beta and interleukin- 6 in human fetal serum and meconium-stained amniotic fluid. J Reprod Immunol 37:155-161

20. Holopainen R, Soukka H, Halkola L, Kaapa P 1998 Meconium aspiration induces a concentration-dependent pulmonary hypertensive response in newborn piglets. Pediatr Pulmonol 25:107-113

21. Wiswell TE, Henley MA 1992 Intratracheal suctioning, systemic infection, and the meconium aspiration syndrome. Pediatrics 89:203-206

22. McKlveen RE, Ostheimer GW 1987 Resuscitation of the newborn. Clin Obstet Gynecol 30:611-620

23. Fineman JR, Soifer SJ, Heymann MA 1991 The role of pulmonary vascular endothelium in perinatal pulmonary circulatory regulation. Semin Perinatol 15:58-62

24. Perlman EJ, Moore GW, Hutchins GM 1989 The pulmonary vasculature in meconium aspiration. Hum Pathol 20:701-706

25. Fox WW, Duara S 1983 Persistent pulmonary hypertension in the neonate: diagnosis and management. J Pediatr 103:505-514

26. Panaro MA, Acquafredda A, Lisi S, Lofrumento DD, Trotta T, Satalino R, Saccia M, Mitolo V, Brandonisio O 1999 Inducible nitric oxide synthase and nitric oxide production in Leishmania infantum-infected human macrophages stimulated with interferon-gamma and bacterial lipopolysaccharide. Int J Clin Lab Res 29:122-127

27. Thiemermann C 1997 Nitric oxide and septic shock. Gen Pharmacol 29:159-166

28. Wong HR, Carcillo JA, Burckart G, Kaplan SS 1996 Nitric oxide production in critically ill patients. Arch Dis Child 74:482-489

29. Aikio O, Vuopala K, Pokela ML, Hallman M 2000 Diminished inducible nitric oxide synthase expression in fulminant early-onset neonatal pneumonia. Pediatrics 105:1013-1019

30. Weinberg JB 1998 Nitric oxide production and nitric oxide synthase type 2 expression by human mononuclear phagocytes: a review. Mol Med 4:557-591

31. Orman KL, Shenep JL, English BK 1998 Pneumococci stimulate the production of the inducible nitric oxide synthase and nitric oxide by murine macrophages. J Infect Dis $178: 1649-1657$

32. Taylor MJ, Cross HF, Bilo K 2000 Inflammatory responses induced by the filarial nematode Brugia malayi are mediated by lipopolysaccharide-like activity from endosymbiotic Wolbachia bacteria. J Exp Med 191:1429-1435 
33. Ajizian SJ, English BK, Meals EA 1999 Specific inhibitors of p38 and extracellular signal-regulated kinase mitogen-activated protein kinase pathways block inducible nitric oxide synthase and tumor necrosis factor accumulation in murine macrophages stimulated with lipopolysaccharide and interferon-gamma. J Infect Dis 179:939-944

34. Ignarro LJ, Buga GM, Wood KS, Byrns RE, Chaudhuri G 1987 Endothelium-derived relaxing factor produced and released from artery and vein is nitric oxide. Proc Nat Acad Sci USA 84:9265-9269

35. Kamijo R, Shapiro D, Le J, Huang S, Aguet M, Vilcek J 1993 Generation of nitric oxide and induction of major histocompatibility complex class II antigen in macrophages from mice lacking the interferon gamma receptor. Proc Natl Acad Sci USA 90:6626-6630

36. Furchgott RF, Zawadzki JV 1980 The obligatory role of endothelial cells in the relaxation of arterial smooth muscle by acetylcholine. Nature 288:373-376

37. Finkel MS, Oddis CV, Jacob TD, Watkins SC, Hattler BG, Simmons RL 1992 Negative inotropic effects of cytokines on the heart mediated by nitric oxide. Science 257:387-389

38. Kinsella JP, Abman SH 2000 Clinical approach to inhaled nitric oxide therapy in the newborn with hypoxemia. J Pediatr 136:717-726

39. The Neonatal Inhaled Nitric Oxide Study Group 1997 Inhaled nitric oxide in full-term and nearly full-term infants with hypoxic respiratory failure [published erratum appears in N Engl J Med 1997;337:434]. N Engl J Med 336:597-604
40. Kinsella JP, Truog WE, Walsh WF, Goldberg RN, Bancalari E, Mayock DE, Redding GJ, deLemos RA, Sardesai S, McCurnin DC, Moreland SG, Cutter GR, Abman SH 1997 Randomized, multicenter trial of inhaled nitric oxide and high-frequency oscillatory ventilation in severe, persistent pulmonary hypertension of the newborn. J Pediatr 131:55-62

41. Holopainen R, Aho H, Laine J, Halkola L, Kaapa P 1999 Nitric oxide inhalation inhibits pulmonary apoptosis but not inflammatory injury in porcine meconium aspiration. Acta Paediatr 88:1147-1155

42. Fernandez-Martorell P, Rais-Bahrami K, Rivera O, Seale WR, Short BL 1998 Use of nitric oxide in meconium aspiration syndrome: lack of response. Scand J Clin Lab Invest 58:177-181

43. Chen F, Castranova V, Shi X, Demers LM 1999 New insights into the role of nuclear factor-kappaB, a ubiquitous transcription factor in the initiation of diseases. Clin Chem 45:7-17

44. Srinivasan HB, Vidyasagar D 1999 Meconium aspiration syndrome: current concepts and management. Compr Ther 25:82-89

45. Hidalgo HA, Helmke RJ, German VF, Mangos JA 1992 The effects of cyclosporine and dexamethasone on an alveolar macrophage cell line (NR8383). Transplantation 53:620-623

46. Barnes PJ, Pedersen S 1993 Efficacy and safety of inhaled corticosteroids in asthma: Report of a workshop held in Eze, France, October 1992. Am Rev Respir Dis 148(suppl):S1-S26 